\title{
Unexpected parasitism of Douglas-fir seed chalcid limits biocontrol options for invasive Douglas-fir in New Zealand
}

\author{
Sonia Lee ${ }^{1}$, Simon V. Fowler ${ }^{1 *}$, Claudia Lange ${ }^{1}$, Lindsay A. Smith ${ }^{1}$ and Alison M. Evans ${ }^{2}$ \\ ${ }^{1}$ Manaaki Whenua - Landcare Research, Lincoln, 7608, New Zealand \\ ${ }^{2}$ Christchurch City Council, PO Box 73054, Christchurch 8154, New Zealand
}

*Corresponding author: fowlers@landcareresearch.co.nz

(Original submission received 16 October 2020; accepted in revised form 5 October 2021)

\begin{abstract}
Douglas-fir seed chalcid (DFSC) Megastigmus spermotrophus, a small (3 mm long) host-specific seedpredatory wasp, was accidentally introduced into New Zealand in the 1920s. Concern over DFSC reducing Douglas-fir seed production in New Zealand led to an attempt at biocontrol in 1955 with the release, but failed establishment, of the small (2.5 mm long) parasitoid wasp, Mesopolobus spermotrophus. We investigated why DFSC causes little destruction of Douglas-fir seed in New Zealand (usually <20\%) despite the apparent absence of major natural enemies. Douglas-fir seed collections from 13 New Zealand sites yielded the seed predator (DFSC) but also potential parasitoids, which were identified using morphology and partial COI DNA sequencing. DFSC destroyed only $0.15 \%$ of Douglas-fir seed. All parasitoids were identified as the pteromalid wasp, Mes. spermotrophus, the host-specific biocontrol agent released in 1955. Total parasitism was 48.5\%, but levels at some sites approached 90\%, with some evidence of density-dependence. The discovery of the parasitoid Mes. spermotrophus could indicate that the biocontrol agent released in 1955 did establish after all. Alternatively, Mes. spermotrophus could have arrived accidentally in more recent importations of Douglas-fir seed. The high level of parasitism of DFSC by Mes. spermotrophus is consistent with DFSC being under successful biological control in New Zealand. Suppression of DFSC populations will benefit commercial Douglas-fir seed production in New Zealand, but it also represents the likely loss of a potential biological control agent for wilding Douglas-fir.
\end{abstract}

Keywords Pseudotsuga menziesii, Megastigmus spermotrophus, Mesopolobus spermotrophus, parasitoid, seed production, biological control

\section{INTRODUCTION}

Douglas-fir, Pseudotsuga menziesii (Mirb.) Franco, has been planted extensively in New Zealand, primarily for timber production, but several commercial seed orchards have also been established for domestic and export purposes (Low 1994; Ledgard et al 2005). Unfortunately, Douglas-fir has naturalised and become a serious weed, invading and transforming high-country landscapes and fragile native ecosystems above the snowline (Webb et al. 1988; Allen \& Lee 1989). Among wilding conifer species in New Zealand, Douglas-fir is of particular concern because of the recent increase in planted area and its shade-tolerant seedlings that allow it to establish within native shrublands and forests (Cleary 1982; Dickson 2001; Ledgard 2002; Froude 2011).

Douglas-fir is the only plantation conifer species in New Zealand that is attacked by an exotic seed-predator, the Douglas-fir seed chalcid (DFSC), Megastigmus spermotrophus Wachtl. (Hymenoptera: Torymidae) (Kay 1994). DFSC is a small (3-mm long) wasp that was introduced into New Zealand accidentally in Douglas-fir seed in the 1920s (Bain 1977). DFSC is a host-specific predator of Douglas-fir seed.
DFSC is now widespread in New Zealand but according to Bain (1977) "the effect of this insect on Douglas fir seedproduction is not great but locally, in certain years, the losses can exceed 20\%". In contrast, DFSC can destroy a high percentage (up to $100 \%$ ) of Douglas-fir seed production as an introduced seed predator in Europe (Mailleux et al 2008; Jarry et al 1997). Our investigation was prompted by the relatively low level of Douglas-fir seed destruction by DFSC in New Zealand, which seemed surprising given the apparent lack of natural enemies attacking the chalcid in New Zealand. There also appeared to be no recent data in New Zealand on the ecology of DFSC, either as a pest of commercial Douglas-fir seed nurseries, or as a potential biocontrol agent to reduce the invasiveness of Douglas-fir as a wilding conifer.

As a predator of valued Douglas-fir seed crops, both in its native range in North America and as an exotic pest in Europe, the life cycle of DFSC has been well-researched (Hussey 1955; Hedlin et al 1980; Nuttall 1989; Mailleux et al 2008): here we summarise the features of the DFCS lifecycle reported by these authors that are relevant to the current 
study. Female DFSC oviposit in very young Douglas-fir seeds in immature pods in early summer. DFSC larvae typically consume the entire contents of the seed, becoming mature by late summer of the same year. The mature DFSC larvae then enter a winter diapause, remaining inside the seed until the following spring. Most larvae then pupate and emerge from the seeds soon after as adults, but about $20 \%$ of the mature larvae of DFSC enter a prolonged diapause, pupating and emerging as adults in subsequent springs a year or more later. Douglas-fir seed falls from mature cones from late summer, through autumn, winter and the following spring. Thus, adult DFSC can emerge from seed either in cones, or from seed that has fallen from the parent tree. A proportion of the seed that falls from the parent tree will contain larvae of DFSC that have entered prolonged diapause, so adult DFSC may not emerge from these seeds on the ground for a year or more. The DFSC larvae and pupae in these seeds are thus likely to be exposed to a different set of mortality factors compared with the DFSC that emerge from seed in a cone that is still attached to the parent tree. The complexity of the DFSC lifecycle means that a thorough study of its attack levels and natural enemies would also be complex. The current study was intended as a preliminary investigation of seed destruction rates by DFSC, and possible parasitism or predation of this seed predator, across a range of sites in New Zealand. Unexpected parasitism or predation of DFSC in New Zealand clearly would be one possible explanation for the reportedly low levels of seed destruction in New Zealand.

DFSC in New Zealand could have acquired natural enemies, including parasitoids, from the existing indigenous and adventive fauna in New Zealand (Paynter et al 2010), but there was also a past attempt to control DFSC biologically in New Zealand: in 1955 a small (2.5 mm long), parasitoid wasp, Mesopolobus spermotrophus Hussey (Hymenoptera: Pteromalidae) (Nuttall 1989) was released in New Zealand because of concerns over DFSC reducing Douglas-fir seed production. Sporadic surveys of Douglas-fir seed up to the late 1980s failed to find any Mes. spermotrophus, so it was assumed the parasitoid failed to establish (Nuttall 1989). There do not appear to have been any more recent surveys for natural enemies of DFSC in New Zealand. Mesopolobus spermotrophus is host-specific and ectoparasitic, with adults ovipositing on mature DFSC larvae only in late summer. The female parasitoids can only access seed containing host larvae once the cone-scales have opened, which occurs in Douglas-fir when the cones reach maturity in late summer (Hussey 1955, 1960). Sample timing is therefore critical to successful field collection of the parasitoid: if mature cones are sampled before they have opened and begun to lose seeds (as they are for commercial collection of Douglas-fir seed, to avoid seed loss), then no parasitism will be found as female Mes. spermotrophus will not have been able to get access to DFSC-infested seed. Sampling only unopened cones of Douglas-fir is thought to explain why the presence of this parasitoid was apparently missed for many years in parts of continental Europe (Mailleux et al 2008). In this study, we collected Douglas-fir seed from already-open, overwintered cones on trees in a New Zealand spring, and reared/dissected insects from the seed to measure the level of seed destruction by DFSC and to detect any larval or pupal parasitoids.

\section{MATERIALS AND METHODS}

\section{Seed collection and insect rearing}

Douglas-fir seed was collected from three North Island and ten South Island Douglas-fir stands in New Zealand during October and November 2019. These cones would have matured, and the cone scales would have opened, initiating seed-fall, at the end of the previous summer (March in the Southern hemisphere) (Table 1). At each site, ten mature cones were collected randomly from the lower $8 \mathrm{~m}$ of each

Table 1 Douglas-fir cone collection sites in New Zealand, listed by increasing latitude.

\begin{tabular}{lllll}
\hline $\begin{array}{l}\text { Geographical } \\
\text { location }\end{array}$ & Site & Latitude & Longitude & $\begin{array}{l}\text { Elevation } \\
\text { (masl) }\end{array}$ \\
\hline North Island & Karioi Forest & $39.4504 \mathrm{~S}$ & $175.5968 \mathrm{E}$ & 742 \\
North Island & Waiouru South & $39.5491 \mathrm{~S}$ & $175.6860 \mathrm{E}$ & 762 \\
North Island & Palmerston North & $40.3864 \mathrm{~S}$ & $175.5839 \mathrm{E}$ & 22 \\
South Island & Belgrove & $41.4796 \mathrm{~S}$ & $172.8747 \mathrm{E}$ & 245 \\
South Island & St Arnaud & $41.7838 \mathrm{~S}$ & $172.8928 \mathrm{E}$ & 714 \\
South Island & Hanmer Springs & $42.5801 \mathrm{~S}$ & $172.6364 \mathrm{E}$ & 509 \\
South Island & Arthur's Pass & $43.0301 \mathrm{~S}$ & $171.6468 \mathrm{E}$ & 660 \\
South Island & McHughs Forest Park & $43.4742 \mathrm{~S}$ & $172.0977 \mathrm{E}$ & 219 \\
South Island & Lake Heron & $43.4945 \mathrm{~S}$ & $171.1593 \mathrm{E}$ & 708 \\
South Island & Mayfield & $43.9293 \mathrm{~S}$ & $171.3469 \mathrm{E}$ & 228 \\
South Island & Burkes Pass & $44.0464 \mathrm{~S}$ & $170.6828 \mathrm{E}$ & 508 \\
South Island & Ben Ohau Station & $44.2337 \mathrm{~S}$ & $170.0538 \mathrm{E}$ & 528 \\
South Island & Central Southland & $45.9635 \mathrm{~S}$ & $168.2157 \mathrm{E}$ & 420 \\
\hline
\end{tabular}


of 10 trees. After collection, cones were examined, and any signs of herbivory or seed predation recorded. All seeds were removed from each cone, examined for signs of natural enemy attack, placed in a Petri dish, and maintained at $16 \mathrm{~h}$, light, $20^{\circ} \mathrm{C}$ and $8 \mathrm{~h}$, dark, $14^{\circ} \mathrm{C}$ to allow insect emergence.

Emerging insects were removed and card-mounted at 2-3 week intervals from November 2019 to January 2020. By early-February 2020, no further emergence of wasps had occurred from the seeds for several weeks. During mid-February and March 2020, the remaining intact seed was then dissected to detect DFSC larvae that had entered prolonged diapause, any other internal biota (e.g. pupal or adult DFSC, or parasitoids, that had failed to emerge) or any other causes of seed mortality. DFSC larvae dissected out of seed were preserved in $96 \%$ ethanol. Several seeds with exit holes made by emerging DFSC or parasitoids were dissected under a binocular microscope.

The percentage of Douglas-fir seed destroyed by DFSC was calculated using the number of emerged adult DFSC (a), the number of larvae found in prolonged diapause (l) and the number of emerged parasitoids (p) and the total seed collected (n) $(\%$ seed destroyed $=100 *(a+l+p) / n)$.

\section{Parasitoid identification}

We used a morphological key (Graham 1969), and partial sequencing of the COI gene, to identify the emerged parasitoids. Each individual parasitoid was assigned to a "recognisable taxonomic unit" (RTU) based on external appearance, and one individual from each RTU was then used for DNA analysis. Close-up images were taken from all specimens prior to the destructive DNA extraction (using photo-stacking with an Olympus TG-5 camera and LG-1 Light Guide). DNA was extracted using the NucleoSpin Tissue kit, Macherey-Nagel, Duren, Germany. A 602 bp partial sequence of the COI gene was amplified and sequenced with primers LCOI490JJ (5' CHACWAAYCATAAAGATATYGG) and HC02198JJ (5'AWACTTCVGGRTGVCCAAARAATCA) (Astrin \& Stuben, 2008). The sequences were used in a blastn search in GenBank, accessions for blast results and other available Mesopolobus spp. were downloaded, and a consensus phylogenetic tree was generated using Geneious Tree Builder (HKY distance model, Neighbor-Joining method, Leptocybe invasa as outgroup), incorporated in Geneious ${ }^{\circledR}$ 10.2.6 (Biomatters Ltd., Auckland).

\section{RESULTS}

\section{Seed collection and insect rearing}

The number of seeds per 10 cones at each site ranged between 835 at Burkes Pass and 2704 at Palmerston North (Table 2). We found no evidence of damage from herbivory or seed predation in the collected cones. Seed extracted from the cones also had no signs of damage from seed predators, e.g. chewing damage or emergence holes.

Twelve adult DFSC emerged from the seeds in the Petri dishes in November and December 2019, each leaving an emergence hole in the seed as expected (Bain 1977),

Table 2 The number of Douglas-fir seeds collected, number of DFSC adults that emerged from seeds (a), the number of DFSC larvae found by seed dissection (1), and the number of Mesopolobus spermotrophus parasitoids emerging from seeds (p), from 13 sites around New Zealand. The percentage seed destruction by DFSC and the percentage parasitism of DFSC are also presented.

\begin{tabular}{|c|c|c|c|c|c|c|c|}
\hline Site & $\begin{array}{c}\text { Date } \\
\text { sampled }\end{array}$ & $\begin{array}{l}\text { No. } \\
\text { seeds } \\
\text { per site } \\
\text { (n) }\end{array}$ & $\begin{array}{l}\text { No. } \\
\text { emerged } \\
\text { DFSC } \\
\text { adults } \\
\text { (a) }\end{array}$ & $\begin{array}{l}\text { No. DFSC } \\
\text { larvae } \\
\text { dissected } \\
\text { from } \\
\text { seeds (l) }\end{array}$ & $\begin{array}{l}\text { No. emerged } \\
\text { Mesopolobus } \\
\text { spermotrophus } \\
\text { parasitoids (p) }\end{array}$ & $\begin{array}{c}\text { Douglas-fir } \\
\text { seeds destroyed } \\
\text { by DFSC }(\%) \\
{\left[100^{*}(\mathrm{a}+\mathrm{l}+\mathrm{p}) / \mathrm{n}\right]}\end{array}$ & $\begin{array}{c}\text { Parasitism by } \\
\text { Mesopolobus } \\
\text { spermotrophus } \\
(\%) \\
{\left[100^{*} \mathrm{p} /\right.} \\
(\mathrm{a}+\mathrm{l}+\mathrm{p})]\end{array}$ \\
\hline Karioi Forest & $6 / 11 / 19$ & 1659 & 0 & 0 & 0 & 0.00 & \\
\hline Waiouru South & $12 / 11 / 19$ & 2115 & 4 & 1 & 1 (male) & 0.28 & 16.7 \\
\hline Palmerston North & $6 / 11 / 19$ & 2704 & 0 & 0 & 0 & 0.00 & \\
\hline Belgrove & $26 / 10 / 19$ & 948 & 0 & 0 & 0 & 0.00 & \\
\hline St Arnaud & $25 / 10 / 19$ & 2404 & 0 & 0 & 0 & 0.00 & \\
\hline Hanmer Springs & $25 / 10 / 19$ & 1322 & 0 & 1 & 7 (3 male, 4 female) & 0.61 & 87.5 \\
\hline Arthur's Pass & $10 / 10 / 19$ & 1979 & 0 & 0 & 0 & 0.00 & \\
\hline McHughs Forest Park & $10 / 10 / 19$ & 1245 & 2 & 1 & 0 & 0.24 & 0.0 \\
\hline Lake Heron & $6 / 11 / 19$ & 951 & 3 & 0 & 0 & 0.32 & 0.0 \\
\hline Mayfield & $1 / 11 / 19$ & 2132 & 0 & 0 & 0 & 0.00 & \\
\hline Burkes Pass & $1 / 11 / 19$ & 835 & 2 & 2 & 0 & 0.48 & 0.0 \\
\hline Ben Ohau Station & $31 / 10 / 19$ & 1613 & 1 & 0 & 8 (6 male, 2 female) & 0.56 & 88.9 \\
\hline Central Southland & $12 / 11 / 19$ & 1500 & 0 & 0 & 0 & 0.00 & \\
\hline Totals across sites & & 21,407 & 12 & $\mathbf{5}$ & 16 & 0.15 & 48.5 \\
\hline
\end{tabular}


(Table 2). Five mature larvae, consistent with the description of mature DFSC larvae in prolonged diapause in Hussey (1955), were found when the remaining intact seed was dissected in February/March 2020. No other insects or damage was noted when the seeds were dissected. A total of 17 DFSC were thus recovered from the 21407 seeds collected in this study.

Sixteen small pteromalid wasps emerged from seeds during December 2019 and January 2020, leaving similar emergence holes to those produced in seeds where DFSC had emerged. Dissection of seeds from which the pteromalids had emerged suggested they were primary parasitoids: there were small amounts of larval remains that appeared to be from a mostly consumed DFSC host, as well as a wasp pupal case. The unidentified pteromalids emerged from seeds collected from 3 sites where DFSC had also emerged (Table 2).

\section{Parasitoid identification}

Each of the parasitoids was placed into a "recognisable taxonomic unit" (RTU) based on physical appearance. RTU1 contained all the male specimens from 3 sites (representative example, Fig 1, left) but the females were split into RTU2 from the Ben Ohau site (smaller, darker green individuals, Fig 1, centre) and RTU3 from the Hanmer site (larger, bronze individuals, Fig 1, right).

The males (RTU1) keyed out to Mesopolobus spermotrophus Hussey using the detailed characters in Graham (1969). The two RTUs of female parasitoids also keyed out to Mes. spermotrophus in Graham (1969), although some of the characters used in the key appeared uncertain with the smaller, darker RTU2 (Fig 1, centre).

We extracted DNA successfully from three selected specimens and sequenced part of the COI gene. The specimens used for DNA extraction were: i) 1 male parasitoid (Ben Ohau) - representing RTU1; ii) 1 female parasitoid (Ben Ohau) representing RTU2; and iii) 1 female parasitoid (Hanmer) representing RTU3. The $602 \mathrm{bp}$ partial COI sequences obtained were identical for the two females tested (RTU2 and RTU3) (Fig 2) despite their morphological differences (Fig 1). The $602 \mathrm{bp}$ partial COI sequence for the male parasitoid differed by 7 single bp $(1.2 \%)$ from the sequence for the females (Fig 2). The identical COI partial sequences of the morphologically variable large and small female specimens in our collections, suggests they are variable individuals of the same species. The $1.2 \%$ difference in the partial COI sequence of the one male tested probably also represents within-species variation in COI, a conclusion that was supported by further phylogenetic analysis (below). Unfortunately, there were no publicly available COI sequences for Mes. spermotrophus in GenBank for comparison to our sequences. However, a blast search revealed partial COI sequence data available for 13 other species of Mesopolobus in GenBank. The sequence alignment represented 68 sequences and was 405 bp long. Our three COI partial sequences appeared as a new cluster in the consensus phylogenetic tree (Fig. 3). The results from the morphological and DNA-based taxonomy combined suggest that our specimens are all Mes. spermotrophus, the parasitoid that was released in New Zealand in 1955 as a biocontrol agent for DFSC, but reportedly failed to establish. One existing sequence in GenBank (Accession MG507824, family Pteromalidae) had $99.7 \%$ identity to our male and 98.5\% identity to our female samples (Fig 3). GenBank gives the collection site for this specimen in the Rocky Mountains near Calgary, Canada which lies within the native range of Douglas-fir. According to our analysis, it is likely that this specimen is Mes. spermotrophus.

\section{Percentage seed destruction and parasitism}

Seed destruction by DFSC varied by site from $0 \%$ (at 7 of 13 sites) to $0.61 \%$, with an overall level of $0.15 \%$ (Table 2 ). We collected Douglas-fir seed in spring from cones that would have already shed some seed when they opened late in the previous summer. Thus, we do not know what the DFSC infestation levels were in seed that had already dropped from the cones prior to our sampling.

Parasitism of DFSC by Mes. spermotrophus was calculated (Table 2: $100^{*} \mathrm{p} /(\mathrm{a}+\mathrm{l}+\mathrm{p})$ ) using both the number of emerged adult DFSC (a) and the number of DFSC larvae that had entered prolonged diapause (l), as both these groups would have been exposed to potential parasitism when the cone scales opened late in the previous summer. Overall

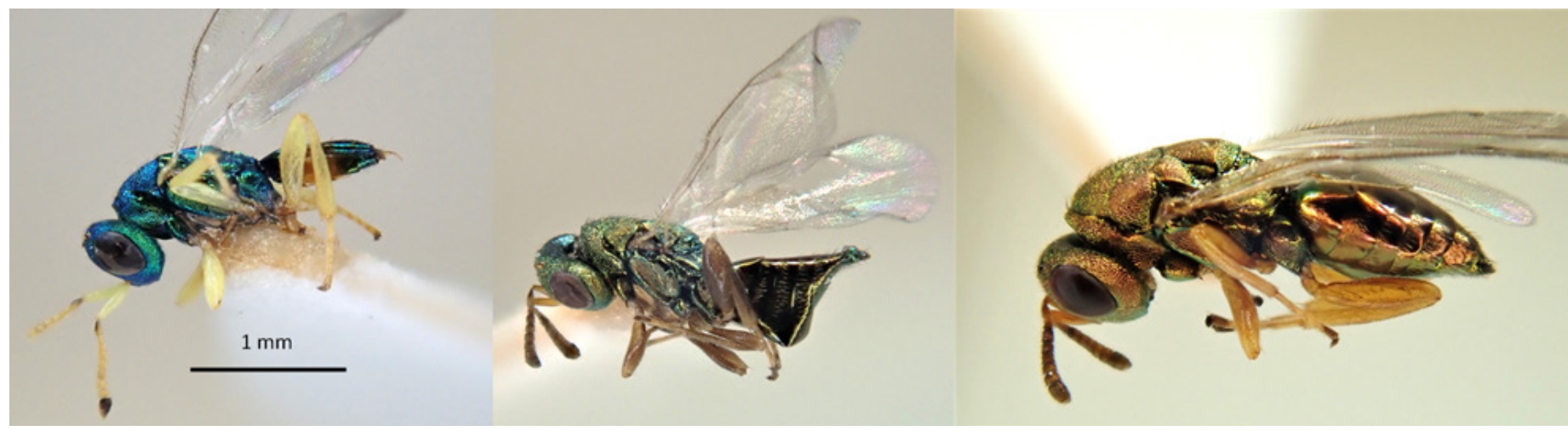

Figure 1 Representative parasitoids emerging from Douglas-fir seed infested with Douglas-fir seed chalcid. Male (RTU1) left. Female (RTU2) centre (Ben Ohau site). Female (RTU3) right (Hanmer site). Scale bar applies to all three specimens. All specimens were identified as Mesopolobus spermotrophus. See text for further details. 


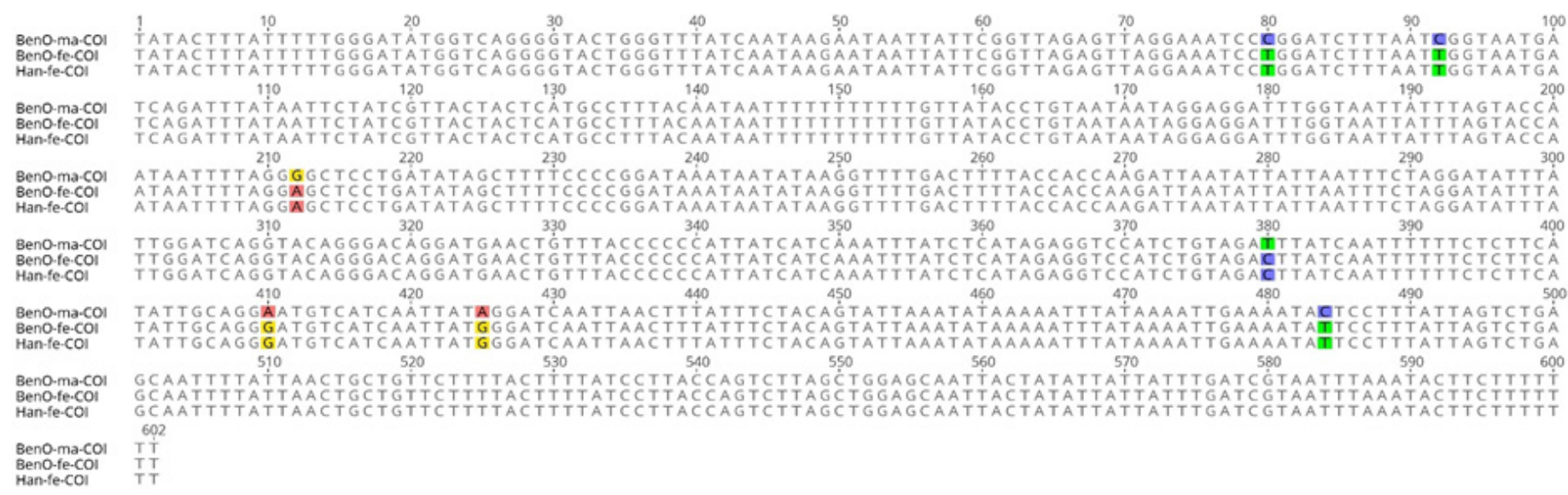

Figure 2 Partial COI 602 bp sequences for the three representative Mesopolobus spermotrophus (BenO-ma-COI - male, RTU1 from Ben Ohau; BenO-fe-COI - small female from Ben Ohau, RTU2; Han-fe-COI - large female from Hanmer, RTU3).

percentage parasitism was $48.5 \%$ (0-88.9\% per site) and showed some evidence of positive density-dependent relationship, but the data were too limited to warrant statistical analysis (Fig. 4). As for the DFSC infestation rates (above), we do not know what the levels of parasitism were in seed that had already dropped from the cones prior to our sampling. We do know that once seed or cones have dropped from the parent tree, any mature larvae of DFSC in the seeds are no longer attacked by Mes. spermotrophus i.e. the parasitoid only attacks DFSC inside seeds in cones that remain on the parent trees, and only for a brief window of time in late summer (Hussey 1955).

The number of seeds collected per site, the percentage of seed attacked by DFSC, and the percentage parasitism, showed no relationship with elevation or geography (latitude or South v. North Islands).

\section{DISCUSSION}

The overall percentage of Douglas-fir seed attacked by DFSC in this study was less than $1 \%$. Since our data were collected in only one season, this result is consistent with (Bain 1977) who reported that "the effect of this insect on Douglas fir seedproduction is not great but locally, in certain years, the losses can exceed 20\%". Our late, post-winter seed collection could have biased our data for both the levels of attack by DFSC and the levels of parasitism (e.g. if seed falling early from cones had higher or lower levels of infestation than the seeds we sampled). However, much more chronologically thorough seed collections, starting when cones mature in later summer and continuing throughout winter and following spring/ summer, would be needed to test for such possible bias. At present, neither our data, nor the overall level of seed destruction reported by Bain (1977), suggest that DFSC is likely to be reducing the invasiveness of Douglas-fir as an environmental weed in New Zealand. In contrast, studies from mainland Europe, where DFSC is an exotic introduction, have reported significantly higher rates of seed predation (up to $100 \%$ ), although levels of attack vary depending on seasonal levels of seed production, climatic differences, pressure from parasitism, or the clonal variety of the Douglas-fir host (Schowalter \& Haverty 1989; Mailleux et al. 2008).
The serendipitous discovery of Mes. spermotrophus in this study is the first report of this parasitoid in the field in New Zealand. Both morphological examination and analysis of the partial DNA COI sequence were useful to confirm the identity of the parasitoid. Although this species was released as a biocontrol agent in New Zealand in 1955, it seems unlikely that its establishment would have remained undetected until now. However, Mes. spermotrophus was overlooked in parts of mainland Europe for many years because Douglas-fir seed was usually collected before the seeds were parasitised (Mailleux et al 2008). Understanding that the parasitoid can only attack its host once the cone scales have opened (Hussey 1955; Mailleux et al. 2008) is critical to sampling Douglas-fir seed in a way that allows detection of the parasitoid. To minimise seed losses from cones, it is common to collect Douglas-fir seed in cones that are mature but have not yet opened (Mailleux et al. 2008). Thus, it is possible that Mes. spermotrophus was missed in New Zealand for a substantial time, and perhaps even did establish after its release in 1955. However, it is also likely that Mes. spermotrophus arrived in New Zealandas more recent accidental incursions in imported Douglas-fir seed. Large amounts of Douglas-fir seed were imported into New Zealand for genetic improvement of Douglas-fir as a commercial crop between the 1950s and 1980s (Miller \& Knowles 1994), and Douglas-fir seed infested with DFSC and/or its parasitoids shows no external differences from healthy seeds (Hussey 1955; Hedlin et al 1980).

We did not sample any Douglas-fir seed orchards for DFSC in New Zealand. However, we predict that levels of seed destruction by DFSC will usually be low in Douglas-fir seed orchards unless they are close to existing Douglas-fir stands: harvesting in seed orchards aims to remove all cones each year, requiring DFSC to re-colonise annually (Jarry et al. 1997). Douglas-fir cones are typically harvested for seeds before the cones have opened, so any DFSC infesting the seeds should not have been exposed to the parasitoid, Mes. spermotrophus. If our assumptions are correct, Douglas-fir seed from harvested, unopened cones in Douglas-fir seed orchards may have low levels of DFSC infestation, but will be free of Mes. spermotrophus. 


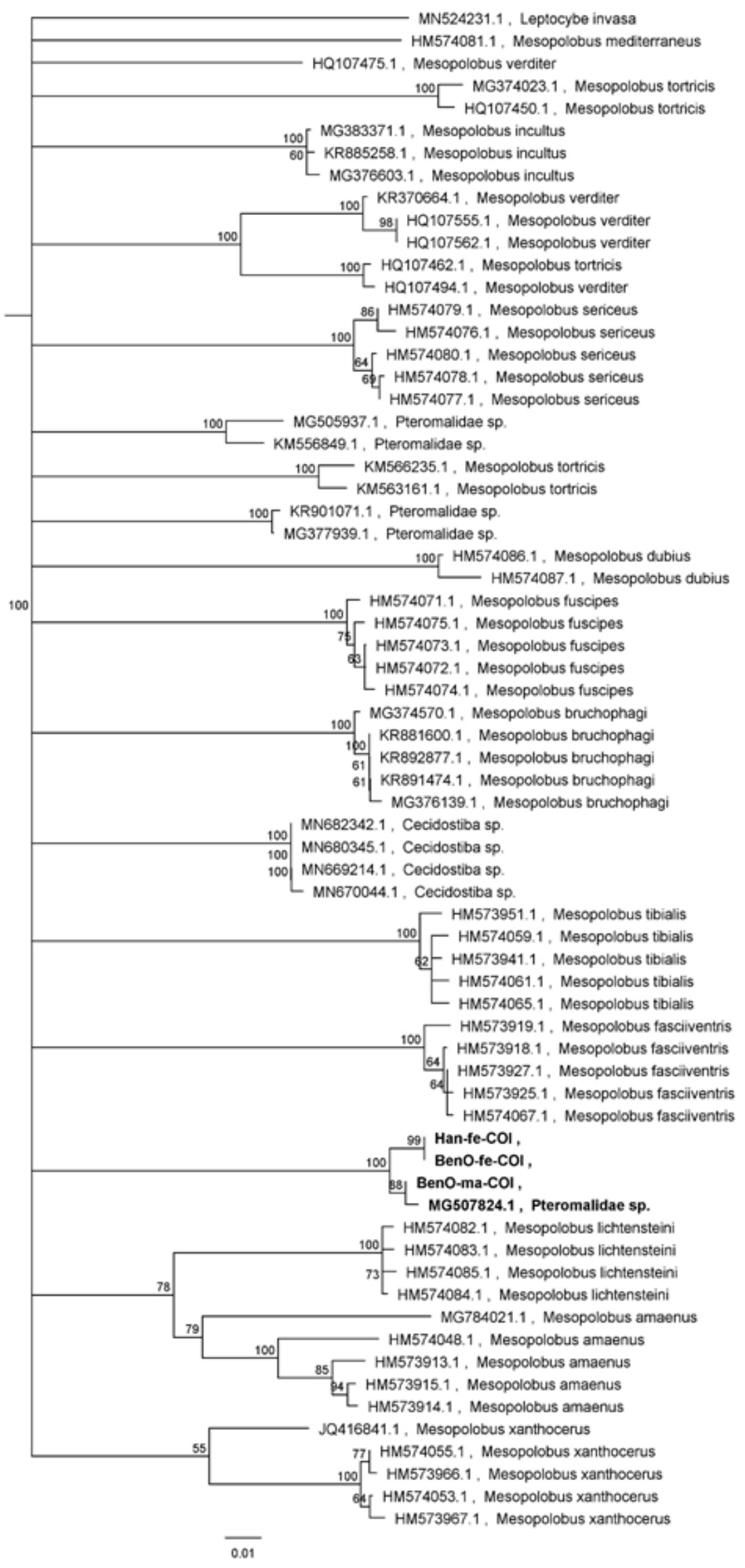

Figure 3 Consensus phylogenetic tree with the three partial COI sequences for our parasitoids (clustered in bold with one other accession from Genbank). The scale bar indicates the branch lengths (nucleotide substitutions per site). Data other than our three partial sequences were sourced from Genbank. 


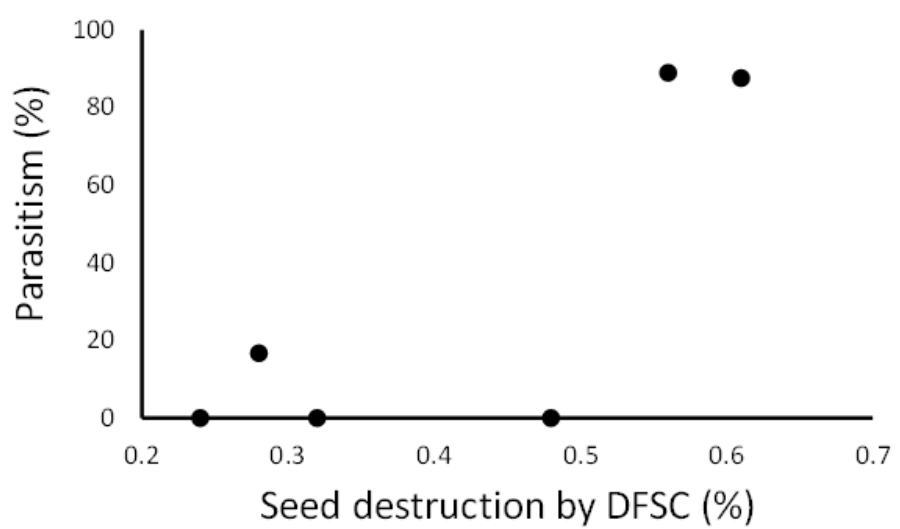

Figure 4 The relationship between percentage parasitism by Mes. spermotrophus and percentage seed destruction by Douglas-fir seed chalcid (DFSC).

The overall percentage parasitism of DFSC in this study was $48 \%$, which is well above the threshold of c. $30 \%$ parasitism reported by Hawkins and Cornell (1994) to be sufficient for successful biological control of arthropod pests. Although this data is from a 'snapshot' sample in spring 2019, if this level of parasitism is common in New Zealand, then it is plausible that DFSC itself is under successful biological control in New Zealand. A more detailed, multi-year study would be required to provide more definitive data. If our preliminary findings are correct, then the successful biological suppression of DFSC is clearly bad news for landowners trying to control wilding Douglasfir and good news for commercial Douglas-fir seed orchards in New Zealand. The high levels of parasitism of DFSC by Mes. spermotrophus almost certainly negates any further interest in DFSC as a potential biocontrol agent for wilding Douglas-fir seed in New Zealand.

\section{ACKNOWLEDGEMENTS}

Paul Peterson (MWLR) and Randal Milne (Southland Regional Council) assisted with seed collections. Funding was from the Ministry of Business, Innovation and Employment (Winning Against Wildings programme and core research funds to Manaaki Whenua - Landcare Research). Graham Burnip, Incursion Investigator, Plant Health Biosecurity Surveillance \& Incursion Investigation team, Ministry for Primary Industries (New Zealand Government) and Darren Ward (New Zealand Arthropod Collection) agreed with our identification of Mes. spermotrophus as a new species in New Zealand in 2020. Comments from the NZPPS editor and two anonymous referees greatly improved the manuscript. Data used to generate the phylogenetic tree in Fig. 3 were obtained from Genbank https://www.ncbi.nlm.nih.gov/ genbank/.

\section{REFERENCES}

Allen RB, Lee WG 1989. Seedling establishment microsites of exotic conifers in Chionochloa rigida tussock grassland, Otago, New Zealand. New Zealand Journal of
Botany 27: 491-498. https://doi.org/10.1080/002882 5X.1989.10414133

Astrin JJ, Stuben PE 2008. Phylogeny in cryptic weevils: molecules, morphology and new genera of western Palaearctic Cryptorhynchinae (Coleoptera: Curculionidae). Invertebrate Systematics 22: 503-522. https://doi.org/10.1071/IS07057

Bain J 1977. Megastigmus spermotrophus Wachtl (Hymenoptera: Chalcidoidea: Torymidae). New Zealand Forest Service, Forest and Timber Insects in New Zealand No.14. Forest Research, Rotorua, New Zealand.

Cleary EA 1982. Ecological aspects of Douglas-fir invasions of mountain beech forest on Ben Lomond Reserve in Queenstown, New Zealand. MSc Dissertation, University of Otago, New Zealand.

Dickson A 2001. The invasion of Douglas-fir (Pseudotsuga menziesii) into Mountain Beech (Nothofagus solandri var. cliffortioides) forest on Burnt Face, Craigieburn Conservation Park. B. For. Sc. Dissertation, University of Canterbury, New Zealand.

Froude VA 2011. Wilding conifers in New Zealand: Status report. Report prepared for the Ministry of Agriculture and Forestry. Pacific Eco-Logic, Bay of Islands. 206 p. https://www.wildingconifers.org.nz/assets/Uploads/ Wilding-Conifer-Status-Report.pdf

Graham MWR de V 1969. The Pteromalidae of NorthWestern Europe (Hymenoptera: Chalcidoidea.) Bulletin of the British Museum (Natural History) Entomology Supplement 16: 1-908. https://doi. org/10.5962/p.258046

Hawkins BA, Cornell HV 1994. Maximum parasitism rates and successful biological control. Science 266: 18861887. https://doi.org/10.1126/science.266.5192.1886

Hedlin AF, Yates HO III, Cibrian-Tovar D, Ebel BH, Koerber TW, Merkel EP 1980. Cone and seed insects of North American conifers. Environment Canada / Canadian Forestry Service, Ottawa, Canada, USDA Forest Service, Washington, DC, and Secretaría de Agricultura y Recursos Hidráulicos, Mexico City, Mexico.

Hussey NW 1955. The life-histories of Megastigmus spermotrophus Wachtl (Hymenoptera: Chalcidoidea) and its principal parasite, with descriptions of the developmental stages. Transactions of the Royal Entomological Society of London 106: 133-151. https:// doi.org/10.1111/j.1365-2311.1955.tb01266.x

Hussey NW 1960. Two new species of Mesopolobus Westwood (Hym., Pteromalidae) with notes on other parasites of Megastigmus Dalman (Hym., Torymidae). Entomologist's Monthly Magazine 95: 237-239.

Jarry M, Candau J-N, Roques A, Ycart B 1997. Impact of emigrating seed chalcid, Megastigmus spermotrophus Wachtl (Hymenoptera: Torymidae), on seed production in a Douglas-fir seed orchard in France and modelling of orchard invasion. Canadian Entomologist 129: 7-19. https://doi.org/10.4039/Ent1297-1

Kay M 1994. Biological control for invasive tree species. New Zealand Forestry 39: 35-37. 
Ledgard N 2002. The spread of Douglas-fir into native forests. New Zealand Journal of Forestry 47: 36-38.

Ledgard N, Knowles L, De La Mare P 2005. Douglas-fir - the current New Zealand scene. New Zealand Journal of Forestry 50, 13-16.

Low C 1994. A brief history of Douglas-fir in New Zealand. New Zealand Journal of Forestry 39: 28-30.

Mailleux A, Roques A, Molenberg J, Grégoire J 2008. A North American invasive seed pest, Megastigmus spermotrophus (Wachtl) (Hymenoptera: Torymidae): its populations and parasitoids in a European introduction zone. Biological Control 144: 137-141. https://doi. org/10.1016/j.biocontrol.2007.10.028

Miller J, Knowles K 1994. Introduced forest trees in New Zealand: recognition, role and seed source 14: Douglas-fir Pseudotsuga menziesii. [FRI Bulletin No. 124], Ministry of Forestry, Forest Research Institute, Rotorua, New Zealand.

Nuttall MJ 1989. Megastigmus spermotrophus Wachtl, Douglas-fir seed chalcid (Hymenoptera:Torymidae). In: Cameron PJ, Hill RL, Bain J, Thomas WP eds. A review of biological control of invertebrate pests and weeds in New Zealand 1974-1987. CAB International, Wallingford, UK.

Paynter Q Fowler SV, Gourlay AH, Groenteman R, Peterson PG, Smith L, Winks CJ 2010. Predicting parasitoid accumulation on biological control agents of weeds. Journal of Applied Ecology 47, 575-582. https://doi. org/10.1111/j.1365-2664.2010.01810.x

Schowalter TD, Haverty MI 1989. Influence of host genotype on Douglas-fir seed losses to Contarinia oregonensis (Diptera: Cecidomyiidae) and Megastigmus spermotrophus (Hymenoptera: Torymidae) in Western Oregon. Environmental Entomology 18: 94-97. https:// doi.org/10.1093/ee/18.1.94

Webb CJ, Sykes WR, Garnock-Jones PJ 1988. Flora of New Zealand. Volume IV Naturalised pteridophytes, gymnosperms, dicotyledons. Department of Scientific and Industrial Research, Christchurch, New Zealand. 